\title{
Text-Based Language Teaching in the New-Normal Era to Achieve Communicative Competence: Challenges for EFL Teachers
}

\author{
Katharina Rustipa ${ }^{1}$, Yulistiyanti ${ }^{2}$, Sri Mulatsih ${ }^{3}$ \\ Universitas Stikubank (UNISBANK) semarang, Indonesia ${ }^{1,2}$ \\ Universitas Dian Nuswantoro, Indonesia ${ }^{3}$ \\ Email Correspondence: katrin@edu.unisbank.ac.id
}

\section{Background:}

\section{Abstract}

To live in this communicative era, people need to have communicative competence. The main aim of ELT is to enable the students to communicate or to produce a text. Thus, EFL teaching needs to facilitate them to achieve communicative competence to participate actively in their communities. EFL teachers can utilize text-based teaching to realize this. Text-based teaching involves the use of texts, which are context bases for achieving communicative competence. This paper describes the common teachers' problems in implementing text-based teaching, especially under the COVID-19 pandemic.

\section{Methodology:}

Open-ended survey questions were delivered to 15 research participants. The researchers followed up their answers with an interview via a telephone call to understand the research participants' opinions.

\section{Findings:}

The questionnaire, interview, and teachers' self-written reflection revealed the teachers' common problems in implementing text-based teaching, i.e., selecting texts, adapting, or modifying texts, designing tasks, and overcoming students' boredom, besides the difficulties of online teaching.

\section{Conclusion:}

The main root of the problems is the teachers' lack of knowledge of the text-based approach. Thus, updating the teachers' knowledge can be one of the solutions to the problems.

Keywords: text-based teaching; communicative competence; online teaching.

DOI $\quad:$ http//dx.doi.org/10.24903/sj.v6i2.763

\begin{tabular}{|c|c|c|}
\hline Received & : & August 2021 \\
\hline Accepted & : & September 2021 \\
\hline Published & : & October 2021 \\
\hline Copyright Notice & : & $\begin{array}{l}\text { Authors retain copyright and grant the journal right of first publication with the } \\
\text { work simultaneously licensed under a Creative Commons Attribution 4.0 } \\
\text { International License that allows others to share the work with an acknowledgement of } \\
\text { the work's authorship and initial publication in this journal. } \\
\text { cc) (i) () }\end{array}$ \\
\hline
\end{tabular}




\section{INTRODUCTION}

We live in a world of texts, surrounded with texts everywhere, spoken, written, offline, online. It is language in texts that people produce for communication in their real life, not as isolated sentences (Thornbury, 2005). In communicating, communicators exchange meaning. When people communicate with each other meaningfully, they create a text together. And when people write meaningfully for others, they also create a text (Agustien, 2020).

The statements above imply that we should expose our students to English texts and facilitate them to engage with English texts because the language in the form of texts actually happens for communication. We call this strategy as text-based teaching. Yet, in practice, the implementation of text-based teaching in Indonesia has raised various problems (Triastuti, 2011). The problems have been getting more significant since the outbreak of the COVID-19 pandemic, the teachers' knowledge of what and how to implement it can minimize the problems.

The implementation of text-based teaching has started since the implementation of a competence-based curriculum in 2004. This is the current trend in EFL teaching and learning (Arimbawa, 2012). As EFL teachers, we need to apply linguistics to language education. The current linguistics is systemic functional linguistics. Text-based teaching derives from systemic functional linguistics. It emphasizes teaching and learning at the text level because communication happens at the discourse level, at the text level. It is discourse or text competence the ultimate goal of language teaching and learning.

De Jager (2012) affirms the importance of communicative competence for language learners. He suggests that language users develop language skills and need to gain communicative competence, i.e., linguistic, and pragmatic competence, which refers to effectively using language in any particular context. Communicative competence involves grammatical competence and contextual or sociolinguistic competence (Canale \& Swain, 1980). Communicative competence includes the knowledge of the language and the capability to understand and use the language appropriately for communication purposes (Mart, 2018). It refers to the capability of making correct utterances and utilizing them appropriately (Mart, 2018). Thus, communicative competence refers to the ability to know when, how, and what to say to whom.

Celce-Murcia (2018) proposes a model of communicative competence consisting of six types of competence: discourse competence, linguistic competence, formulaic competence, interactional competence, sociocultural competence, and strategic competence. 
By mastering different kinds of texts, EFL learners will develop their communicative competence because communicating means using various kinds of spoken and written texts in the specific context of their use (Arimbawa, 2012).

The term text-based teaching used in this paper refers to teaching using a genre/textbased approach. The genre-based approach (GBA) derives from Halliday's theory of language as social semiotic, i.e., language as a resource for making meaning (Hasan, 2014). The genre theorists opine those teachers are responsible for intervening in the learning process, and they should teach how genres are typically constructed (Emilia, 2005).

GBA has pedagogical and political aims. It is a pedagogical project motivated by a political project, i.e., to teach and facilitate someone to have skills and knowledge enabling them to participate effectively in a literate, technologically developed society, to be successful in school and beyond (Kress, 1993; Derewianka, 2015). It encourages reading and writing various text types or genres (Feez \& Joyce, 1998). A model of GBA commonly used is the model of Feez and Joyce, which has five stages as follows: (1) Building the context, (2) Modeling and deconstructing the text, (3) Joint construction of the text, (4) Independent construction of the text, (5) Linking related texts (Feez \& Joyce, 1998).

This paper is reflective based on teachers' belief in text-based teaching to achieve communicative competence and teachers' problems and challenges in implementing textbased teaching, especially in this COVID-19 pandemic. This paper clarified the following problems: (1) How do the teachers perceive text-based language teaching to enhance students' communicative competence? 2) What do the teachers in implementing text-based teaching face the typical problems? (3) What are the common problems faced by the teachers in implementing text-based online teaching? Thus, this current study aims at knowing the teachers' perceptions and their problems in implementing text-based teaching. This paper is significant to open our horizon concerning text-based teaching and contribute to the better implementation.

Researchers have carried out studies on the implementation of text-based teaching. Here are some previous studies. A study conducted at the Post Graduate Program of State Islamic Institute of Tulungagung revealed that text-based learning stimulated a joyful learning environment, activated the students' participation, and improved the students' language skills as their expectation. The researcher stated that this teaching model will not be applicable without the teacher's commitment to solving the implementation problems (Iftanti, 
2017). This current research explored the problems which the teachers in implementing textbased teaching face.

An experimental study at Chinese University compared the effectiveness of text-based approach and dictionary-based approach to teach vocabulary. The research showed that the text-based approach was more effective than the dictionary-based approach in improving the learners' mastery of new words and in retaining the time duration in the learners' memory. The effectiveness of text-based approach to teach vocabulary will be achieved if the teacher can select the proper text and insert the new vocabulary in the text (Qian, 2011). This current research attempts to reveal the teachers' challenges in utilizing texts in implementing textbased teaching.

Genre-based instruction by doing generic structure and linguistic feature analyses of news broadcasts texts significantly improved EFL students' listening comprehension competence (Atai \& Khatibi, 2010). These analyses also improved EFL learners' competence in writing a discussion text. A research result revealed that genre-based teaching improved the students' choices of lexicogrammatical features in a discussion text (Nagao, 2019). Explicit teaching of a genre and exposing authentic texts to ESP students proved to be effective to improve English for hospitality and tourism students' competence to write brochures (Yang, 2012).

The GBA cycles, especially model texts and explicit teaching of a particular grammar, are beneficial to writing similar texts. The research reported that the students and the teachers have a positive impression of the GBA cycles. The students were reported to have more confidence, and the teachers were reported to have more satisfaction with the students' progress (Lin, 2006). Research finding concluded that genre-based pedagogy improved the students' genre awareness and genre writing of the target language. The students' positive remark to the implemented instruction was also reported (Davies, 2014).

Research on 'finding and discussion' sections of undergraduate EFL students revealed the rhetorical moves and the linguistic realizations of the moves. Based on the research result, genre-based pedagogy was recommended to teach English for research publication purposes (Suherdi et al., 2020). Classroom research revealed the effectiveness of text-based intercultural teaching in improving students' intercultural awareness and speaking skills (Permatasari \& Andriyanti, 2021).

A study on text readability found that the genre-based approach improves the readability of EFL students' texts. Explicit genre instruction improved the structure and 
linguistics choices (Albino, 2017). Research also reported that genre-based teaching facilitates the students to write successfully. It enhances the students' awareness of why a text is written in a particular way and form (Wrigglesworth \& McKeever, 2010).

A mix-method study of text-based approach in South Africa revealed that this approach was suitable and advantageous for English education, yet it failed to develop learners' communicative competence. The problem was that the English teachers implemented the text-based approach without in-depth knowledge and consciousness (Mohlabi-Tlaka, 2016). A qualitative multiple-case study revealed the difficulties of implementing text-based teaching methods in selecting and organizing texts for teaching. It was recommended that the teachers be trained with the conceptual and practical knowledge of text-based teaching (Triastuti \& Riazi, 2020).

The previous studies above indicate the effectiveness of text-based teaching. Yet, the implementation needs the teachers who have sufficient knowledge about it and have the awareness to implement it. The differences between the previous studies and this current study are that the previous studies explored the implementation of a text-based approach. The goals of the previous studies are to know the impact of text-based teaching on the learning environment toward the learning outcome covering the language skills, language micro-skills, language elements such as vocabulary, grammar. Unlike the previous studies, this current study explored the teachers' perception of their experience in implementing text-based teaching and revealed their challenges to implementing text-based teaching to achieve communicative competence, especially in this pandemic. To our knowledge, the studies that specifically explored the Indonesian teachers' perception of the text-based approach have not been carried out yet. Revealing teachers' perception is important because their perception will likely influence their teaching practice. The result of the study will give information to policymakers who hopefully will follow it up.

\section{METHODOLOGY}

This study aims to describe the teachers' perception and challenges of Text-Based Approach (TBA) in ELT, especially their challenges to implement text-based online teaching. To achieve the goal, the data were collected through open-ended survey questions and teachers' self-reflection. The following are the open-ended survey questions delivered to 15 research participants:

1. Do you apply TBA in your ELT?

2. Do you believe that text-based teaching can develop the students' communication skills/ can develop the students' communicative competence? 
3. What is your opinion about text-based teaching?

4. How can text-based teaching facilitate your students to develop their communication skills?

5. What are your students' activities in your text-based class?

6. What are your challenges and problems in implementing text-based teaching?

The instruction for the respondents to do self-reflection is as follows:

Share your experience in implementing text-based online teaching in this COVID-19 pandemic by writing a self-reflection.

Survey questions 1-4 are used to elicit the data of the teachers' perception of textbased approach to achieve communicative competence. These 4 survey questions answered the first research question: How do the teachers perceive text-based language teaching to enhance students' communicative competence? Survey question 4 is used to elicit the argument to their perception and opinion.

Survey questions 5 and 6 are used to answer the second research question: What are the common problems faced by the teachers in implementing text-based teaching? Survey question 5 is to know whether the students' activities/ tasks designed by the teacher in every stage are under the TBA theory. Specifically, this is to elicit the problems in designing tasks. Survey question 6 is to elicit the problems and challenges in general.

Self-reflection is used to answer the third research question: What are the common problems faced by the teachers in implementing text-based online teaching? This is to elicit the data on the EFL teachers' challenges to implement text-based online teaching.

Fifteen teachers became respondents of this study, eight university teachers, four senior-high-school teachers, and three junior-high-school teachers. The information about the respondents is illustrated in the table below:

Table 1. Respondents' information

\begin{tabular}{lllll}
\hline Respondents & $\begin{array}{l}\text { Teaching } \\
\text { experience } \\
\text { (years) }\end{array}$ & Age & Gender & $\begin{array}{l}\text { Teaching } \\
\text { location }\end{array}$ \\
\hline 1 & 4 & 27 & Female & Semarang \\
2 & 24 & 50 & Female & Semarang \\
3 & 15 & 40 & Female & Semarang
\end{tabular}




\begin{tabular}{|c|c|c|c|c|}
\hline 4 & 5 & 30 & Male & Semarang \\
\hline 5 & 9 & 35 & Female & Semarang \\
\hline 6 & 6 & 29 & Female & Semarang \\
\hline 7 & 6 & 28 & Male & Semarang \\
\hline 8 & 18 & 42 & Female & Semarang \\
\hline 9 & 5 & 26 & Male & Semarang \\
\hline 10 & 4 & 25 & Female & Semarang \\
\hline 11 & 6 & 27 & Female & Semarang \\
\hline 12 & 6 & 28 & Male & Semarang \\
\hline 13 & 10 & 32 & Female & Semarang \\
\hline 14 & 9 & 29 & Female & Semarang \\
\hline 15 & 11 & 35 & Female & Semarang \\
\hline
\end{tabular}

The researchers sent the survey questions and the self-reflection instruction to the research participants via e-mail. Then, they also sent their answers via e-mail. The researchers followed up their answers with an interview via a telephone call to get a comprehensive understanding of the research participants' opinions. Having got sufficient data, the researchers analyzed the data qualitatively, supported with TBA theory.

\section{FINDINGS}

The open-ended survey questions, interview, and teachers' self-written reflection revealed the following findings: 
Text-Based Language Teaching in the New-Normal Era to Achieve Communicative Competence:

\subsection{The teachers' perception toward text-based language teaching.}

All of the respondents agreed on the implementation of text-based teaching. Their answers to the following three survey questions revealed their belief and opinion toward TBA.

1. Do you apply TBA in your ELT?

2. Do you believe that text-based teaching can develop the students' communication skills/ can develop the students' communicative competence?

3. What is your opinion about text-based teaching?

All of the 15 participants answered 'yes' to the first question responding to the government recommendation. All of the participants also answered 'yes' to the second survey question, but their 'yes' answer or belief is followed by a condition, i.e. the appropriate implementation. They are optimistic that the appropriate implementation can develop the students' communicative competence. However, the inappropriate implementation may not achieve students' communicative competence. Thus, they have optimism and pessimism. The research participants' optimism and pessimism of text-based teaching were shown by their answers to survey question 4: How can text-based teaching facilitate your students to develop their communication skills? Here are some examples of the arguments put forward by some respondents.

Q45:

"By only acquiring vocabulary and grammar of English, the students will not be able to communicate in English effectively. Learning English texts will make the students able to communicate in English more effectively. But, the classroom texts should be appropriate"

Q48:

"Indonesian and English texts have a different convention. To be familiar with English text types, the students need to learn the English text types in depth. Thus, text-based teaching is suitable. However, the implementation in the classroom often meets problems."

Q413:

"Teaching English genres make the students aware that there is a rule in texts. It makes them aware that the kind of text that they produce depends on the communicative purpose. Text-based teaching provides examples and conventions of text types. Thus, the competence in selecting texts is important"

\subsection{Common problems faced by EFL teachers in implementing text-based teaching}

The respondents mentioned various problems in implementing text-based teaching which can be summarized in table 1 . 
Table 2. Problems in implementing text-based teaching

\begin{tabular}{llll}
\hline No & Problems & Frequency & Sample perceptions \\
\hline 1 & In selecting texts & 11 & $\begin{array}{l}\text { It is not easy in selecting texts. I was sometimes } \\
\text { confused whether the texts that I selected were } \\
\text { appropriate for the student's level and interest. } \\
\text { (Q61) }\end{array}$ \\
$\begin{array}{l}\text { In adapting, } \\
\text { modifying texts }\end{array}$ & 14 & $\begin{array}{l}\text { I found difficulties how to modify my chosen texts } \\
\text { to match with the learning objectives (Q611). }\end{array}$ \\
$\begin{array}{l}\text { In designing the } \\
\text { tasks }\end{array}$ & 16 & $\begin{array}{l}\text { I often found difficulties to realize the learning } \\
\text { outcome in classroom activities. Sometimes, I was } \\
\text { unsure what tasks I should give in each stage. } \\
\text { (Q63) }\end{array}$ \\
$\begin{array}{l}\text { In overcoming the } \\
\text { students' boredom }\end{array}$ & 3 & $\begin{array}{l}\text { I found that the application of the five-phase cycle } \\
\text { for teaching all English language skills sometimes } \\
\text { made the students bored. (Q62) }\end{array}$ \\
\hline
\end{tabular}

\subsection{EFL teachers' challenges to implementing text-based online teaching}

To reveal the teachers' challenges to implementing text-based online teaching in this COVID-19 pandemic, the researchers asked them to share their experiences by writing selfwritten reflections. The data showed that all of them have conducted synchronous and asynchronous learning modes. The synchronous learning mode was carried out via virtual classrooms, chat boxes, instant messaging. The asynchronous learning mode was carried out by (1) asking the students to learn the learning materials uploaded by the teachers, e.g. ppt., videos, (2) asking the students to do assignments, (3) asking the students to enrich their understanding by browsing from other sources.

The respondents mentioned various problems in implementing online text-based teaching which can be summarized in table 2 .

Table 3. Problems in implementing online text-based teaching

No Problems $\quad$ Frequency Sample perceptions

1 Students' low $\quad 10 \quad$ Sometimes the class situation was not conducive motivation because of the students' low motivation. Some students were reluctant to participate in-class activities. (R4)

2 Technical problems 6

Audio-visual quality sometimes hampered the online teaching process. (R10)

$3 \quad$ Internet connection 6

Poor internet connection sometimes hampered the 
teaching process. (R6)

$4 \quad$ ICT literacy

5 Interaction

6

Students' lack of 6 autonomy
7

8

6
My low ICT literacy reduces my self-confidence in implementing online text-based teaching. (R9)

Interaction between teachers and students is limited. The students' collaboration is also limited. (R7)

Students' lack of autonomy also becomes the factor that hampers online text-based teaching. I needed to repeatedly remind my students to submit their tasks. (R12)

\section{DISCUSSION}

The findings above will be discussed in the following sections, by interpreting and relating them with the empirical contexts, TBA theory, and the previous studies.

\subsection{The teachers' perception toward text-based language teaching.}

All of the 15 respondents have ever applied TBA in their English class. They all have responded to the government policy to apply TBA since the implementation of the competence-based curriculum. They all believe that text-based teaching can develop communicative competence if it is properly implemented. So, they have optimism or positive attitudes and also pessimism to the text-based teaching. The problems they faced in the classroom made them feel pessimistic.

The optimism or positive attitudes were mostly conveyed by committed teachers who were aware to upgrade themselves, search the stock of texts, and energize the students with various class activities. They said that the efforts to make text-based teaching interesting increased the students' active participation and satisfied the teachers. This affirms the previous studies' research finding that the students were reported to have more confidence, and the teachers were reported to have more satisfaction with the students' progress (Lin, 2006; Davies, 2014).

Respondent 14 , having a positive attitude toward text-based teaching explained: 'Textbest teaching is a must unless our students will not be able to communicate in English (Q314).' The teacher's positive perception is in line with the rationale underlying the implementation of text-based teaching: the goal of ELT, the learning outcome of text-based teaching. The main goal of ELT is to enable learners to communicate in English, both in 
spoken and written forms. Communicating is making meaning; it is creating a text. And it is language to make meaning that underlies text-based teaching (Eisenring, 2019).

Respondent 15 explained 'Without working with English texts, without being exposed with texts, our students will not be familiar with English texts. Thus, text-based teaching is a required method (Q415).' This positive opinion is in line with a theory that text-based teaching utilizes texts allowing EFL students to explore and interact with the text to comprehend the texts (Eisenring, 2019). The main goal of the modeling stage in text-based teaching is to provide model texts as sufficient comprehensible input for the students that can facilitate them to use oral and written English (Rahman, 2013). This can help learners to build up confidence as language users.

Similar to the above perceptions, respondent 1 explained 'Texts should be the center in our EFL teaching because texts are central in the community practices. Thus, there should be link and match between the teaching content and what the students need (Q41).' This is in line with what Mickan (2017) confirms that the reasons underlying the implementation of text-based teaching are that it trains the students to 1) be familiar with texts, 2) make sense of texts from the beginning, 3) use language for real purpose in lessons, 4) tailor texts to class communities, 5) make meanings.

In a follow up interview, respondent six who is pessimistic about text-based teaching implementation in Indonesia explained:

'Frankly speaking, as a teacher who has taught for years, I still find difficulties in designing tasks for every stage. And some of my friends also have the same problems. Theoretically, text-based teaching is effective to achieve communicative competence. But, it is not effective when the teacher is not competent (IQ66).'

The answers to survey question 5: What are your students' activities in your text-based class? revealed that the activities done in their class are learning the grammar, learning the text structure and linguistic features, reading the written text model, listening to the spoken text model, constructing a text collaboratively, constructing a text independently, observing many kinds of texts, answering questions. However, only three participants asked the students to analyze the texts, to find context in a text. Their reason is that the teaching time allotment is limited.

\subsection{Common problems faced by EFL teachers in implementing text-based teaching}

All of the teachers believed that text-based teaching could facilitate their students to achieve communicative competence if they implemented it properly. They opined that the EFL students' regular exposure and experience with text would make them familiar with 
various English texts. The various classroom activities matched with the learning outcome facilitated the students to achieve communicative competence. However, they were aware that they sometimes even often found difficulties realizing the learning outcome into classroom activities; thus, they were unsure whether the students would achieve the learning outcome. The other common problems that the teachers faced were selecting texts, adapting or modifying texts, designing tasks, and overcoming students' boredom. This finding is similar to previous studies that the problem in implementing a text-based approach was that the English teacher lacked in-depth conceptual and practical knowledge (Mohlabi-Tlaka, 2016; Triastuti \& Riazi, 2020). The common problems faced by the teachers are clarified as follows.

\subsubsection{In selecting texts}

The main objective of teaching English is to facilitate the students to experience and reflect the richness of the English texts. This demands the teacher to select and sequence the texts for the sake of his teaching (Mickan, 2011). This means that the teacher should be creative to find relevant texts for use, to have a stock of texts. In selecting texts, the teacher should consider the learners' interests and the level of difficulty. Yet, 11(73\%) respondents said it was not easy to select texts. They stated that sometimes they were confused about which texts attracted the students and whether the texts selected were appropriate for their level. They were also confused about what authentic texts mean. Here are two respondents' excerpts:

There are a lot of texts in internet with various topics and various genres. Sometimes I'm confused and I need a long time to decide which one to select. Even after selecting the text, sometimes I'm still doubtful whether the text can attract my students who have various backgrounds (Q610).

I'm not sure with the concept of authentic text. Can a text written by an Indonesian writer called as authentic? Or must it be written by a native speaker? (Q65).

This finding is similar to Triastuti's finding revealing three common problems, i.e. the selected texts that did not comply with the learning outcome, the misjudgment of the text complexity level, the text authenticity (Triastuti, 2011).

In TBA, the teacher should expose the students to various text types; however, finding stocks of various texts was also problematic for $5(33 \%)$ respondents. Richards (2006) recommends sources of texts that the teacher can utilize, e.g. procedures in carrying out a task, explaining how and why things occur, reviews, arguments, debates, 
magazine articles, biographies, autobiographies, stories, fables, dialogs, formal/ informal letters, postcards, e-mail, notices (Richards, 2005).

\subsubsection{In adapting, modifying the texts}

The explanation in the previous section indicates that the learners should meet with various texts for various purposes. They will also meet with texts with various levels of authenticity, simplified, semi-authentic, and authentic texts. And the teacher should have text-adaptation strategies. Based on the data, adapting or modifying texts is also problematic for EFL teachers. Fourteen respondents said that they had problems in adapting texts. Respondent 2 said 'Adapting a text is a complicated matter. It takes me a long time to do it. Sometimes, I'm not sure whether the adapted text reflects the original text (Q62).'

Adaptation strategies reduce the difficulty or complexity level and match the texts with our learning objectives. The strategies are among others: shortening, segmenting, simplifying, co-textualizing, glossing (Thornbury, 2005).

\subsubsection{In designing the tasks}

Tasks are students' activities to develop their skills to achieve communicative competence. Teachers' problems in designing tasks can hamper communicative competence achievement. Thirteen respondents wrote that they had problems in designing tasks. In a follow-up interview to clarify the respondents' answers, 3 teachers explained that they sometimes did not have ideas of the tasks that should be given in each stage of TBA. Here is respondent 12 excerpt 'As a teacher, I want my students to have interesting and challenging activities in every stage of TBA. But, sometimes I don't have ideas of what tasks that can challenge my students, to make them study hard (IQ67).'

As introductory activities in the stage of building the context, the teacher can raise the students' awareness of the wordings, the grammar, text types that they will later meet in the lesson. The presentation of model texts in the modeling stage is principally to make the students observe, experience, and process the texts. By asking the students to read or listen to several examples of a text type, the teacher can help them become familiar with the texts.

A text selected for text-based instruction is to stimulate the students to participate actively in the classroom by responding to the texts. Together, the teacher and students 
analyze the texts for building students' discourse or language resources. They can analyze the lexicogrammar, schematic structure, communicative purpose of the texts, etc. Then, the teacher can follow this text analysis by explicit teaching in which they can introduce and explain the technical terms, the grammar, etc.

The communicative goal of text-based teaching is to apply the language resources to express meanings in conversations or compositions, with different text types. The production tasks the teacher can assign to the students are among others doing a role play, discussing issues raised by the texts, having a debate about the points of view presented in the text, writing a similar text, writing a response to the text (Marina \& Marmienè, 2006).

\subsubsection{Students' boredom with routine}

Three respondents said that applying the five-phase cycle for teaching all English language skills sometimes made the students bored: 'Implementing the same cycles in every teaching sometimes made my students bored. They could guess what I would ask them to do (Q614).' This is similar to Marina and Marmiene's (2019) finding stating that the application of a five-phase cycle repeatedly may prove tedious for second language learners. Yet, they remind us that the merits of the five-phase cycle outweigh the demerits, the advantages outweigh the disadvantages (Marina \& Marmiené, 2006). To avoid boredom, teachers need to do creative and innovative actions such as modifying the cycles, using various multimedia to attract the students.

\subsection{EFL teachers' challenges to implementing text-based online teaching}

All of the research participants wrote that regardless of the various problems they faced, they had a positive attitude toward e-learning. This is in line with Fatimah and Santiana (2017) study revealing that technologies promoted the students' attitude toward learning and the teachers' professional development.

The respondents' reflection revealed that the challenges of text-based online teaching are the challenges to overcome the students' low motivation, technical problems, internet connection, ICT literacy, interaction, students' lack of autonomy. Ten respondents have the problems with the students' low motivation which can be seen from the students' reluctance to participate in the class. Respondent 4 wrote 'When I was teaching, some of my students were passive, did not respond to my instruction. They also did not open their camera (R4).' 
Six respondents met with technical (audio-visual quality) and internet connection problems: 'The audio-visual was not clear. Poor internet connection also frequently became the main reason to leave the class or even to cancel the class (R9).'

Seven respondents felt that they lacked ICT literacy. Respondent 2 said 'Lack of ICT literacy reduced my self-confidence and I often felt anxious because of this (R2).' Text-based teaching, especially in the 'Joint construction of the text' stage, demands the students' collaboration or interaction to produce a text. However, 8 participants stated collaboration in online text-based teaching was not easy: 'Creating collaboration among students was difficult. The interaction was limited. Interaction between teacher and students was limited (R3).' The 'Independent construction of a text' stage, especially in online learning, requires more students' autonomy. However, six respondents said that many students failed to be selfregulated learners. Respondent 15 said 'I needed to repeatedly remind my students to submit their tasks (R15).'

\section{CONCLUSION}

Text-based teaching utilizes texts for achieving the learning outcome. Teachers choose the relevant texts that attract the learners' interest, i.e., the texts that happen in their communities, because they will learn well when they learn what is applicable in their lives. Choosing, modifying, and implementing text-based teaching demands innovative thinking and creativity, especially in this covid-19 pandemic.

Text-based teaching expands the students' ability to express meaning appropriately, to communicate in their real life. In other words, text-based teaching enhances their communicative competence. This approach helps learners build up their confidence as language users. Yet, problems arise in the implementation of this approach (especially in this covid-19 pandemic), such as selecting texts, adapting or modifying texts, designing tasks, overcoming students' boredom, and technical and internet connection problems in ICT literacy problem. The teachers can minimize the difficulties with in-depth knowledge of what and how to implement. Thus, it is suggested that the policymakers upgrade the teachers.

The limitation of this study is that the number of respondents is small, only 15. And all of them teach in the same city. It is suggested that future research employs more respondents teaching in various cities. 


\section{REFERENCES}

Agustien, H. I. (2020). Implementing a text-based approach in English language teaching (N. Renandya, Willy A; Hayati (ed.)). TEFLIN Publication Division in collaboration with CV. Bintang Sejahtera.

Albino, G. (2017). Improving readability in an explicit genre-based approach: The case of an EFL workplace context. RELC Journal, 48(3), 311-326. https://doi.org/10.1177/0033688216684279

Arimbawa, I. N. (2012). Text-based approach to efl teaching and learning in Indonesia. PRASI: Jurnal Bahasa, Seni, dan Pengajarannya, 7(13), 9-13.

Atai, M. R., \& Khatibi, M. B. (2010). The effect of genre consciousness-raising tasks on Iranian efl learners' listening comprehension performance. Journal of Asia TEFL, 7(3).

Canale, M., \& Swain, M. (1980). Theoretical bases of communicative approaches to second language teaching and testing. Applied Linguistics, 1(1), 1-47. https://doi.org/10.1093/applin/1.1.1

Celce-Murcia, M. (2008). Rethinking the role of communicative competence in language teaching. In Intercultural language use and language learning (pp. 41-57). Springer. https://doi.org/10.1007/978-1-4020-5639-0_3

Davies, M. (2014). Preparation and implementation of a genre-based approach in a nonacademic efl classroom. Doctoral dissertation, University of Birmingham.

De Jager, L. J. (2012). Misunderstanding in second language instructional communication. Doctoral dissertation, University of Pretoria.

Derewianka, B. M. (2015). The contribution of genre theory to literacy education in Australia. RELC Journal, 34(2), 133-154. https://doi.org/10.1177/003368820303400202

Eisenring, M. A. A. (2019). The use of text-based approach to enhance students' ability in analyzing discourse: A reflective paper. Komposisi: Jurnal Pendidikan Bahasa, Sastra, dan Seni, 20(1), 68-76.

Emilia, E. (2005). A critical genre-based approach to teaching academic writing in a tertiary level efl context in Indonesia. PhD Dissertation. Melbourne University.

Fatimah, A. S., \& Santiana, S. (2017). Teaching in 21st century: Students-teachers' perceptions of technology use in the classroom. Script Journal: Journal of Linguistic and English Teaching, 2(2), 125. https://doi.org/10.24903/sj.v2i2.132

Feez, S., \& Joyce, H. D. S. (1998). Text-based syllabus design. National Centre for English Language Teaching and Research, Macquarie University.

Hasan, R. (2014). Text-based approach to efl teaching and learning in Indonesia. PRASI: Jurnal Bahasa, Seni, dan Pengajarannya. Functional Linguistics, 1(1), 9. https://doi.org/10.1186/s40554-014-0009-y 
Iftanti, E. (2017). Text-based learning (Tbl) to activate adult efl learners in learning English: a narrative inquiry. Jurnal Bahasa Lingua Scientia, 9(1), 121-142. https://doi.org/10.21274/1s.2017.9.1.121-142

Kress, G. (1993). "Genre as social process." The Powers of literacy: A genre approach to teaching writing, 22-37.

Lin, B. (2006). Genre-based teaching and vygotskian principles in EFL: The case of a university writing course. Asian EFL Journal, 8(3).

Marina, V., \& Marmienè, A. (2006). Text-based language teaching and the analysis of tasks presented in English course books for students of information technology and computing. Santalka, 14(2), 99-105. https://doi.org/10.3846/coactivity.2006.25

Mart, C. T. (2018). From communicative competence to language development. International Journal of English Linguistics, 8(2), 163-167. https://doi.org/10.5539/ijel.v8n2p163

Mickan, P. (2011). Text-based teaching: Theory and practice. Monograph on Foreign Language Education. Tokoshima: Tokoshima University.

Mickan, P. (2017). Text-based research and teaching from a social semiotic perspective: Transformative research and pedagogy. In text-based research and teaching (pp. 1535). Springer. https://doi.org/10.1057/978-1-137-59849-3_2

Mohlabi-Tlaka, N. (2016). The contribution of a text-based approach to English education for communicative competence. Doctoral dissertation, University of Pretoria.

Mumba, C., \& Mkandawire, S. B. (2019). The text-based integrated approach to language teaching: Its meaning and classroom application. Multidisciplinary journal of language and social sciences education, 2(1), 123-142.

Nagao, A. (2019). Assessing the development of English learners' understanding of the discussion genre. Journal of Asia TEFL, 16(3), 927. https://doi.org/10.18823/asiatefl.2019.16.3.10.927

Permatasari, I., \& Andriyanti, E. (2021). Developing students'intercultural communicative competence through cultural text-based teaching. Indonesian Journal of Applied Linguistics, 11(1). https://doi.org/10.17509/ijal.v11i1.34611

Qian, T. (2011). A Comparison between the text-based approach and the dictionary-based approach of vocabulary learning in a chinese university.

Yasin, A., \& Rozimela, Y. (2013). The implementation of genre-based approach in English teaching at Islamic senior high school model (MAN Model) Jambi. English Language Teaching (ELT), 1, (3), 36-49.

Richards, J. C. (2005). Communicative language teaching today. SEAMEO Regional Language Centre Singapore. 
Text-Based Language Teaching in the New-Normal Era to Achieve Communicative Competence:

Challenges for EFL Teachers

Katharina Rustipa, Yulistiyanti, Sri Mulatsih

Suherdi, D., Kurniawan, E., \& Lubis, A. H. (2020). A genre analysis of research article 'findings and discussion'sections written by Indonesian undergraduate EFL students. Indonesian Journal of Applied Linguistics, 10(1), 59-72. https://doi.org/10.17509/ijal.v10i1.24989

Thornbury, S. (2005). Beyond the sentence: Introducing discourse analysis. Macmillan Education.

Triastuti, A. (2011). Critical issues in the implementation of genre-based teaching. Retrieved April, 17, 2017.

Triastuti, A., \& Riazi, M. (2020). Indonesian EFL teachers' content conceptualization and course organization: A portray of text-based teaching. Indonesian Journal of Applied Linguistics, 9(3), 526-535. https://doi.org/10.17509/ijal.v9i3.23202

Wrigglesworth, J., \& McKeever, M. (2010). Writing history: A genre-based, interdisciplinary approach linking disciplines, language, and academic skills. Arts and Humanities in Higher Education, 9(1), 107-126. https://doi.org/10.1177/1474022209349987

Yang, W. (2012). Evaluating the effectiveness of genre-based instruction: A writing course of English for hospitality and tourism. The Asian EFL Journal, 13(4), 174-193. 